\title{
EFFECTS OF ORGANIC FERTILIZERS ON THE GROWTH PERFORMANCE, “ICE- ICE” DISEASE OCCURRENCE AND CARRAGEENAN QUALITY OF FARMED SEAWEED KAPPAPHYCUS STRIATUS (F. SCHMITZ) DOTY EX. P.C. SILVA
}

\author{
HADJIRAN A. ILLUD \\ College of Fisheries, Mindanao State University, Tawi - Tawi College of Technology and Oceanography, Sanga - Sanga, \\ Bongao, Tawi-Tawi 7500, Philippines
}

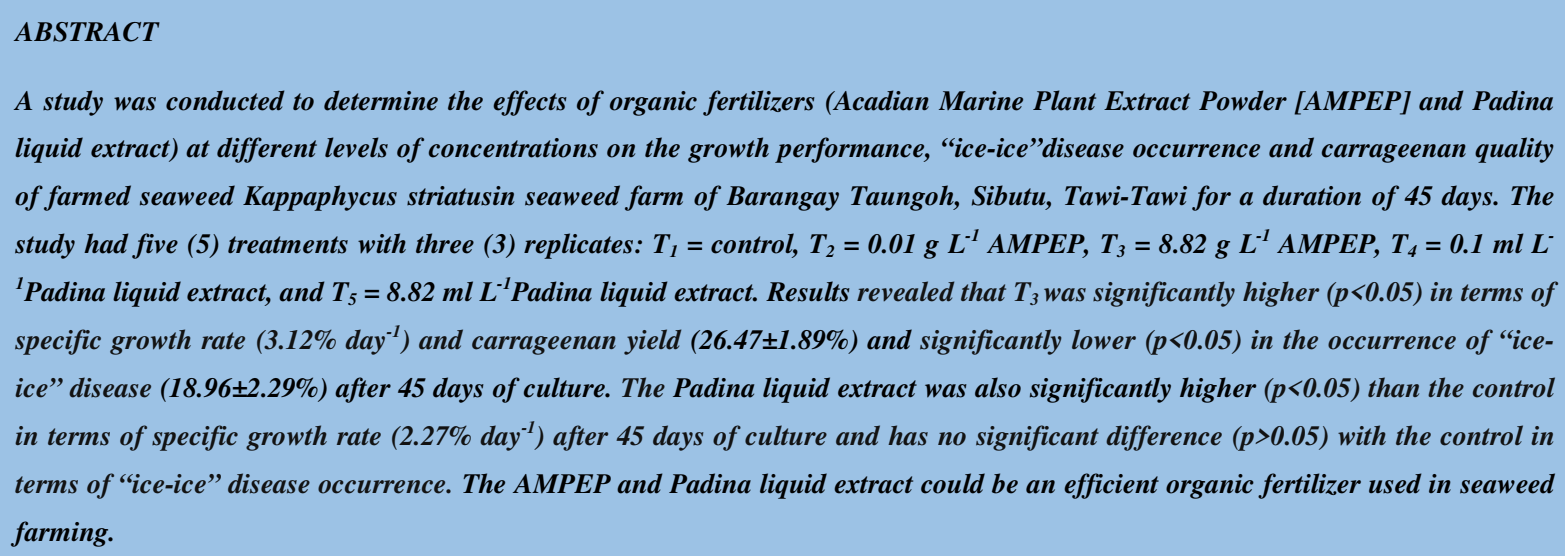

Received: Jun 08, 2020; Accepted: Jun 28, 2020; Published: Sep 12, 2020; Paper Id.: IJMPERDJUN20201176

\section{INTRODUCTION}

The red seaweeds Eucheuma and Kappaphycus had been harvested from the natural stock in commercial scale for export purposes in the late 1950's and early 1960's. Due to high demand of Eucheuma and Kappaphycus for carrageenan production from North American and European processing plants, there was an increase in the exploitation of their wild stock. This situation resulted to the depletion of the wild populations of these red seaweedsand subsequently thisled to the initiative of Dr. Maxwell S. Doty in establishing commercial seaweed farming in Tapaan Island, Siasi, Sulu in the mid - 1960's and in the early 1970's. The seaweed cultivation has expanded to other parts of the country like the Visayas and Luzon, and to other countries like Micronesia, Fiji, East Africa and China (Hurtado and Agbayani 2000). The eucheumatoid seaweed cultivation was further introduced to over 20 countries in Southeast Asia, in the Pacific and the Western Indian Ocean (Hurtado et al. 2013; Msuya et al. 2013).

Kappaphycus, locally known as 'guso' or 'tambalang' constitutes $80 \%$ of the Philippines seaweed export. The Philippines ranked third as major seaweed producer in the world in 2001 after China and Korea (Hurtado 2003). In 2006, the Philippines produced about 1.5 million metric tons equivalent to $70 \%$ of the total aquaculture production. In the Philippines, Eucheuma and Kappaphycus farming increased from around 100,000 metric ton in 
1995 to over 1.1 million metric ton in 2012 (White and Wilson 2015).

However, the outbreaks of "ice-ice"disease occurrence and epiphyte infestation in seaweed farms had caused to poor quality crops (Tisera and Naguit 2009; Pang et al. 2015) and the decrease of Philippine Kappaphycus production (Hurtado et al. 2006). Seaweed farmers have observed that this "ice-ice"disease occurrence and epiphytic filamentus algae infestation mostly caused by low nutrient levels, light intensity, temperature and salinity (Trono 1986). In recent years, seaweed farmers, particularly in Tawi-Tawi province, have developed culture techniques by using inorganic fertilizers to remedy the poor farming output. With the use of inorganic fertilizers, the farmed seaweeds grow faster and could be harvested in shorter culture period (Tahiluddin 2019).

Considering that chemicals from the synthetic fertilizers might have adverse effects on human health and the environment(Nabti et al. 2016), so the use of organic fertilizers is more preferable because these are biodegradable, nontoxic, non-polluting and non-hazardous to humans and other animals (Dhargalkar and Pereira 2005). The AMPEP and brown seaweeds such as Sargassum and Padina were proven to be environmental-friendly fertilizers. Thus, this study was conceived using organic fertilizers for seaweed cultivation. The result of this study could serve as guide to sustainable seaweed farming industry in Tawi - Tawi as well as other seaweed producing regions in the country.

This study aimed to investigate the effects of organic fertilizers on growth performance, "ice-ice" disease occurrence and carrageenan quality of farmed seaweed Kappaphycus This study investigated the effects of organic fertilizers on growth performance, "ice-ice" disease occurrence and carrageenan quality of farmed seaweed Kappaphycus striatus.

\section{LITERATURE CITED}

\section{Status of World Seaweed Farming}

The top seven most cultivated seaweed genera, three are used mainly for hydrocolloid extraction. The red algae Kappaphycus and Eucheuma, are major sources of carrageenan which account for over 80\% of world's carrageenan production (Pereira and Yarish 2008). China produces seaweeds mostly for food i.e. Saccharina japonica (formerly Laminaria japonica), Undaria pinnatifida, Pyropia spp. (formerly Porphyra) and Sargassum fusiforme. On the other hand, Indonesia and the Philippines produce mainly the carrageenophytes Kappaphycus and Eucheuma and Gracilaria spp. for carrageenan and agar respectively (FAO 2016).

In 2014, China and Indonesia were the leading seaweed farming countries, each produced more than 10 million tonnes, the Philippines and the Korean Republic over 1 million tonnes, while the People's Democratic Republic of Korea, Japan, Malaysia and Zanzibar produced over 100000 tonnes (FAO 2016). Kappaphycus and Eucheuma have been cultivated in Indonesia that contributed over 9.0 million tons, over 83\% of global production, mostly Eucheuma; followed by the Philippines nearly 1.4 million tons, $13 \%$ of global production, mostly Kappaphycus. Approximately 340,000 tons of these carrageenophytes were produced from Malaysia, Cambodia, Vietnam, China, Tanzania, Madagascar, Belize and Brazil (Valderrama et al. 2015, Bjerregaard et al. 2016, FAO 2017).

\section{Effects of Fertilization on Seaweeds}

The success of seaweed (Eucheuma/Kappaphycus) farming depends primarily on the natural fertility of the farm site. Seaweed farming fertilization is not yet a common practice throughout the world. In China, the nitrogen enrichment has 
been practiced in Laminaria japonica cultivation since 1956 using the unglazed porous clay bottles, the porous plastic bags, splashing and spraying liquid fertilizers, soaking young sporelings in a fertilizer solution, and natural fertilization through polyculture (FAO 1989).

The nutrient enhancement could promote growth, improve carrageenan quality and reduce the occurrence of "iceice" diseases in farmed Kappaphycusalvarezii. The K.alvarezii enriched with sodium nitrate fertilizer could decrease "iceice" to $8.75 \%$ and become more resilient to diseases. The $K$. alvarezii fertilized with 10ppm sodium nitrate could increase the specific growth rate (SGR) of $1.4 \% \mathrm{day}^{-1}$ (Luhan et al. 2014) while $K$. striatus also fertilized using ammonium phosphate (16-20-0) every 10 days at high concentration $\left(8.82 \mathrm{gL}^{-1}\right)$ doubled the SGR of $3.75 \%$ day $^{-1}$ even during "ice-ice" season (Tahiluddin 2019). Fertilization is not a common practice worldwide. In the Philippines, particularly in Tawi-Tawi province, the seaweed farmers have started Kappaphycus fertilization using agricultural fertilizers to increase production and minimize "ice-ice" occurrence since 2013 (Tahiluddin 2019). Sodium nitrate enrichment in farmed Kappaphycus alvarezii could provide better growth, good quality carrageenan and protection against "ice-ice" disease (Luhan et al. 2014). The seaweed based organic fertilizers generally contain 60 trace minerals which are essential for plant's health and growth. The use of organic fertilizers is a sustainable alternative to chemical fertilizers which might have detrimental effects in the environment. The synthetic fertilizers such as Nitrogen - Phosphorous - Potassium (NPK) may have different nutrient concentrations (Vitosh 1996). Every nutrient has specific role and function for plant growth. The nitrogen (N), phosphorous $(\mathrm{P})$ and potassium $(\mathrm{K})$ are necessary for photosynthesis, metabolism and physiological activities (Uchida 2000). The seaweed based organic fertilizers also contain nutrients, minerals and several important growth stimulators such as auxins, hormones, gibberellins, indoles, and cytokinins (Nabti et al. 2016).

The Acadian marine plant extract powder (AMPEP) is extracted from brown seaweed Ascophyllum nodosum and it is now used worldwide for large scale seaweed cultivation (Rodrigues 2016). Brown seaweed Ascophyllum nodosum extract as contained in AMPEP has been discovered to potentially activate the natural defense system of $K$. alvarezii against (Pramanick et al. 2017).The AMPEP used to fertilized Kappaphycus species can increase daily growth rate of 1.3 $4.1 \%$ day $^{-1}$ and decrease occurrence of epiphyte infestation (Borlongan et al. 2010) and the K. alvarezii fertilized with $10 \mathrm{ppm}$ ammonium could attain the daily growth rate of $4.6 \%$ day $^{-1}$ (Rui et al. 1990). The thalli of $K$. alvarezii infested with "ice-ice" disease reduced in the concentration of photosynthetic so this would cause the loss of its photosynthetic efficiency and resulted to poor growth performance (Ganzon-Fortes et al.1993). Several studies on the nutrient enrichment reported to have improved growth and health on cultivated seaweeds (Topinka 1976; Neish et al. 1977; Harlin and ThorneMiller 1981; Lapoite 1986; Rui et al. 1990; Dawes et al. 1994; Troell et al. 1999; Villares et al. 1999; Menéndez et al. 2002; Borlongan et al 2010; Loureiro et al 2010; Martins et al. 2011; Reef et al. 2012; Zuldin and Shapwi 2015). The fertilization using Ascophyllum nodosum extract for farmed Kappaphycusalvarezii could improve growth and reduce epiphyte infestation (Loureino et al. 2010). The use of Acadian Marine Plant Extract Powder (AMPEP) as fertilizer could also reduce the occurrence of "ice-ice" disease and epiphyte infestation in farmed.

Kappaphycus striatus (Zuldin and Shapawi 2015). The seaweed fertilizers also play a protective role in salinity tolerance by retaining moisture and nutrients in the soil (Sofy et al. 2017). The organic fertilizer derived from brown seaweed Padina pavonica also contains macronutrients such as nitrogen $(\mathrm{N})$, phosphorus $(\mathrm{P})$, potassium $(\mathrm{K})$, magnesium $(\mathrm{Mg})$ and other trace elements which are necessary for development and growth of plants (Chbani et al. 2013). 


\section{Occurrence of Disease on Farmed Seaweeds}

The "ice-ice" disease and infestation of epiphytic filamentous algae (EFA) are two major problems in Eucheuma and Kappaphycus farming. The "ice-ice" disease develops as a result of stresses on the seaweed brought about by unfavorable environmental factors (De San 2012; Largo et al. 1995a). The signs of the disease are that the thalli degenerate, turn into a pale white color and eventually rot (De San 2012). In a farm with slow water movement, the "ice-ice" disease can be also caused by pathogenic bacteria through invading the seaweed thalli (Largo et al.1995b).

The high incidence of epiphytic filamentous algae (EFA) can also contribute to the occurrence of "ice-ice" disease (Uyenco et al. 1981; Trono and Ohno 1989). The epiphyte (Neosiphonia savatieri) infestation happens at high temperature, low salinity and slow water movement and during the period when the farmed seaweeds are vulnerable to "ice-ice" disease (Tisera and Naguit 2009; Hung et al. 2009). The "ice-ice" disease in eucheumatoid seaweed farming usually occurred simultaneously with Neosiphonia savatieri infestation (Pang et al. 2015). Pests and diseases are considered as the major problems in seaweed farming (Azanza and Ask 2017). Hurtado et al. (2006) reported the Polysiphonia outbreaks in the Philippines that caused a decrease in Kappaphycusalvarezii production. The occurrence of epiphytic filamentus algae had also caused a large scale die-off of $K$. alvarezii in China (Pang et al. 2015). The "ice-ice" disease has become a major problem in seaweed industry. The "ice-ice" affected seaweeds become whitish, soft and eventually disintegrate and hence resulted to poor quality crops (Tisera and Naguit 2009). If "ice-ice" is observed at seaweed farm, it is recommended to harvest the entire crop and replace them with the new seedlings or transfer the plants to the unaffected farming area (Arasamuthu and Edward 2016).

\section{Carrageenan Quality of Seaweeds}

The Eucheumatoid species including Eucheuma denticulatum, Kappaphycus alvarezii and $K$. striatus (formerly $K$. striatum) are primary source of the valuable hydrocolloid carrageenan (Bixler and Porse 2011). Carrageenan is a good source of soluble fiber (Burtin 2003). These are species of seaweeds as source of different types of carrageenan: (a) Eucheuma denticulatum (spinosum) - iota carrageenan, (b) Kappaphycus alvarezi (cottonii) and K. striatus - kappa carrageenan, (c) Gigartina radula,Gigartina skottsbergii, Sarcothalia crispata and Chondrus crispus - kappa/lambda carrageenan. These types of carrageenan slightly vary in chemical structures and properties (McHugh 2003). The iota, kappa, and lambda carrageenan have the highest commercial interest.Carrageenan is a versatile product widely used for food and nonfood industries (Van de Velde et al. 2002; Heertje 1993; Hood \& Allen 1977; Swaisgood 1982).

\section{MATERIALS AND METHODS}

\section{Research Locale}

The study was conducted in the seaweed farm of Barangay Taungoh, Sibutu, Tawi-Tawi (4⿳4一𣥂 $\left.42^{\prime} 21^{\prime \prime} \mathrm{N} ; 119^{\circ} 29^{\prime} 34^{\prime \prime} \mathrm{E}\right)$ for 45 days from February 9 to March 23, 2019 (Fig.3.1). 


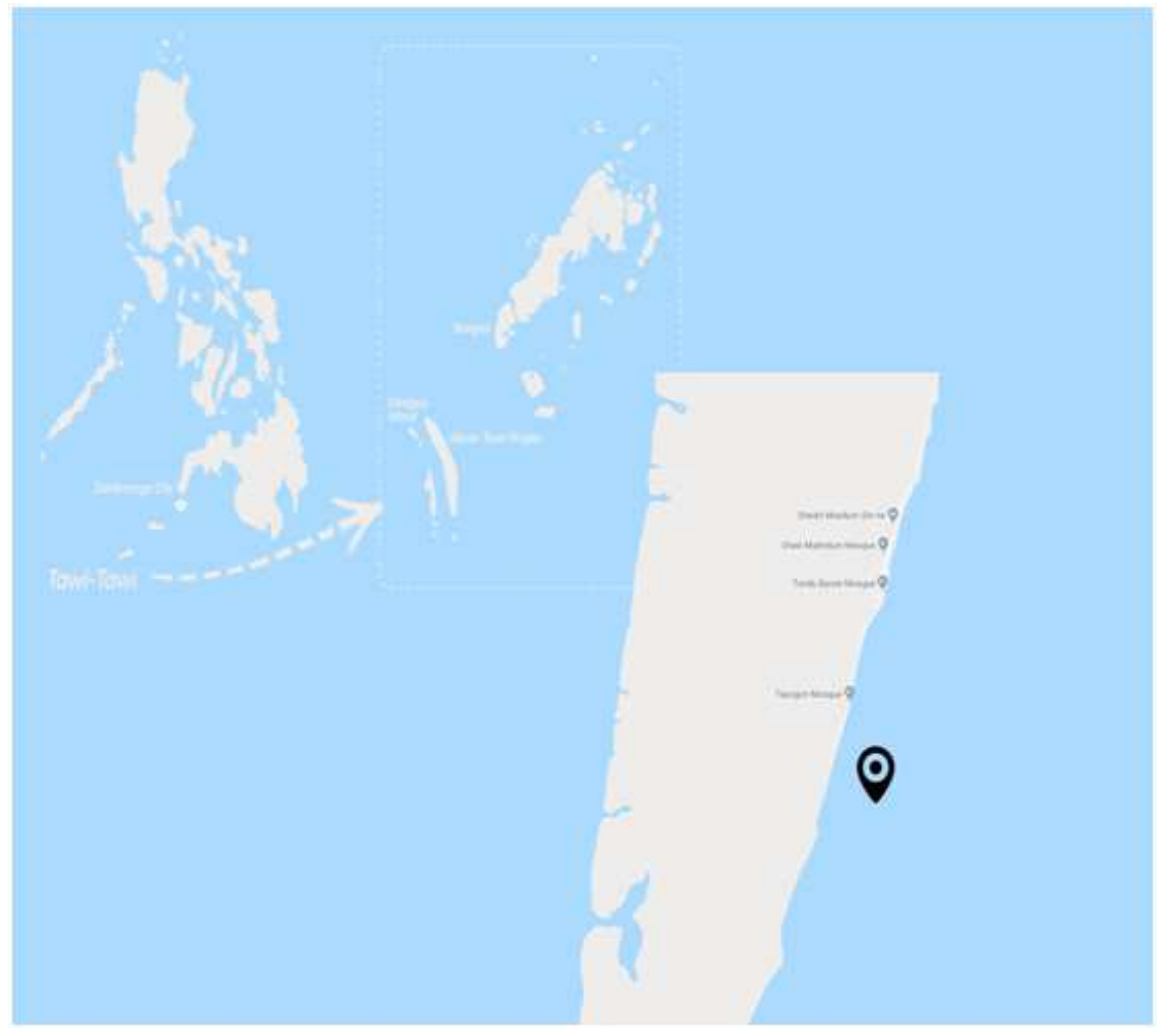

Figure 1: Map ofthe study site (Extracted from Google Earth)

\section{Design}

This study made used of experimental research design. There were five (5) Treatments with three (3) replicates: Treatment $\mathrm{T}_{1}-$ control, $\mathrm{T}_{2}$ - Acadian Marine Plant Extract Powder (AMPEP) $\left(0.01 \mathrm{gL}^{-1}\right.$ low concentration), $\mathrm{T}_{3}-$ Acadian Marine Plant Extract Powder (AMPEP) (8.82 $\mathrm{gL}^{-1}$ high concentration), $\mathrm{T}_{4}-$ Padina liquid extract $\left(0.1 \mathrm{ml} \mathrm{L}^{-1}\right.$ low concentration) and $\mathrm{T}_{5}$ - Padina liquid extract $\left(8.82 \mathrm{ml} \mathrm{L}^{-1}\right.$ high concentration).

\section{Procedures}

\section{$\underline{\text { Fertilizers }}$}

The Acadian Marine Plant Extract Powder (AMPEP) is extracted from brown seaweed Ascophyllum nodosum and it is now commercially available organic fertilizer in global market (Rodrigues 2016).The formulated fertilizer was prepared using a brown algae Padina sp. as sole ingredient since it has been proven as good organic fertilizer (Chbani et al. 2013). Padina $s p$. wascollected from Kalang, Sanga-Sanga, Bongao, Taw-Tawi. The Padina was thoroughly washed using tap water to remove sea salts on the surface of the seaweed. Fresh Padina was cut into small pieces and boiled with 1 liter distilled water for an hour and the extract was filtered through a fine cloth (Kumar and Sahoo 2011). The extract was kept in an empty bottle and stored at room temperature. The formulated fertilizer was in the form of Padina liquid extract.

\section{Farming of Seaweeds}

Healthy, epiphyte - free, unfertilized propagules were purchased from the seaweed farmer in the study area. A bunch of $50 \mathrm{~g}$ propagules was tied into a $5 \mathrm{~m}$ cultivation line (PE rope \#6) with $25 \mathrm{~cm}$ interval (Trono 1992). Three replicate lines were prepared with 20 bunches each line. A total of 15 lines were prepared. 


\section{$\underline{\text { Fertilization }}$}

Fertilization was done late in the afternoon ( $2-6 \mathrm{pm})$. Four (4) different fertilizer solutions were prepared using AMPEP and Padina liquid extract with $0.01 \mathrm{~g} \mathrm{~L}^{-1}$ (Hurtadoand Critchley 2013) and 8.82 $\mathrm{gL}^{-1}$ (Tahiluddin 2019) concentrations for both fertilizers and the control without fertilizer. The tied propagules were dipped into the ten (10) liter fertilizer solutions for 30 seconds, and then covered with canvass overnight (12-15 hours) (Tahiluddin 2019 unpublished data). Refertilization was done every 15 days using newly mixed solutions.

\section{Planting of Seaweeds}

The propagules were planted randomly in the farm using a modified fixed - off bottom method at $0.3 \mathrm{~m}$ above the seabed (Fig. 2). Planting of seaweeds was done in the morning during low tide. Planted seaweeds were monitored every 7 days for cleaning and removal of the attached epiphyte algae and other debris. The environmental parameters were recorded every 7 days. Temperature and salinity were measured using thermometer and refractometer, respectively. The water depth using calibrated rope line and water current velocity using an improvised drogue.

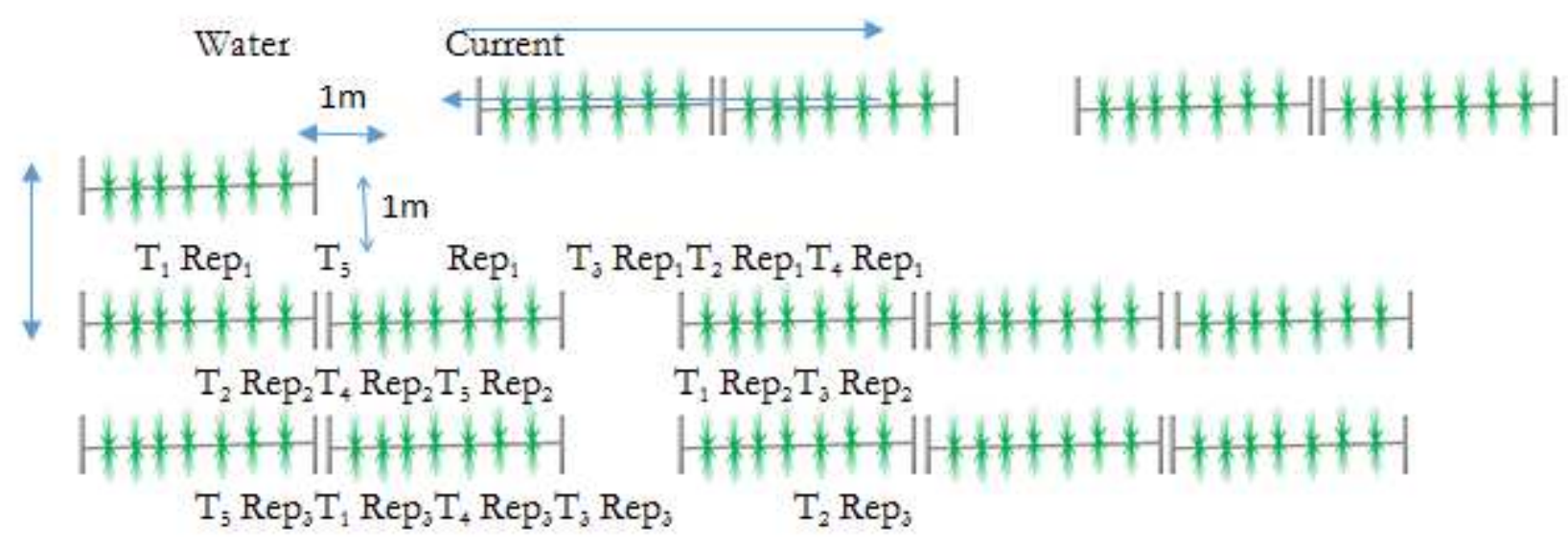

Figure 2: Experimental layout of the farm

\section{Growth Sampling}

Sampling was done every 15 days to determine specific growth rate (SGR). Five (5) bunches of propagules were randomly taken from three replicates for all treatments. The propagules were blot-dried on smooth cloth and then weighed using weighing scale. Growth $(\mu)$ expressed as specific growth rate was computed using formula below (Luhan and Sollesta 2010):

$$
\mu=\frac{\ln (\mathrm{Wf})-\ln (W i)}{\text { Days of culture }} \times 100
$$

where $\mathrm{W}_{\mathrm{f}}$ is the final weight, $\mathrm{W}_{\mathrm{i}}$ is the initial weight and $\ln$ is the natural logarithm.

The occurrence of "ice-ice" disease was monitored every 15 days through visual inspection. Any sign of white and soft branches was considered "ice-ice" (Luhan et al. 2014). The "ice-ice" percentage occurrence of infected seaweeds was calculated using the formula below (Largo et al. 1995a).

$$
\text { "Ice }- \text { ice } " \% \text { occurrence }=\frac{\text { Number of infected bunches }}{\text { Total number of bunches }} \times 100
$$




\section{Extraction of Carrageenan from $K$. striatus}

\section{$\underline{\text { Alkali-treated Carrageenan }}$}

The seaweeds K. striatus was sun-dried for three days. A $20 \mathrm{~g}$ dried seaweed samples from each treatment was prepared for moisture content analysis. The samples were mixed thoroughly. Three (3) replicates of $5 \mathrm{~g}$ samples were taken and analyzed with moisture analyzer.A weight of $200 \mathrm{~g}$ of sun-dried seaweeds $K$. striatus was taken from each treatment for carrageenan extraction. The dried seaweeds were cut into small pieces. Fifteen (15) g samples of dried seaweed from each treatment were soaked in $5 \% \mathrm{KOH}$ solution for 2 hours. The alkali solution was decanted. The treated thalli were heated for one hour. The thalli were washed and $250 \mathrm{ml}$ of purified water was added. The thalli were boiled for one hour and then osterized. The decalite was added to the solution before it was filtered. The filtrate was allowed to cool and gel. The gel was frozen overnight and thawed the following day. The product was alkali-treated carrageenan and it was dried in an oven (Romero 2009; Romero et al. 2000).

\section{Carrageenan Yield}

The dried carrageenan was weighed and recorded. Carrageenan yield was determined using equation below (MohammadAkhmal et al. 2017; Luhan et al.2014; Webber et al. 2012; Muñoz et al. 2004.):

$$
\mathrm{Y}=\frac{\mathrm{Wc}}{\mathrm{Wds}} \times 100
$$

where $\mathrm{Y}$ is the yield of crude carrageenan extract $(\%), \mathrm{W}_{\mathrm{c}}$ is the amount of the extracted alkali-treated carrageenan $(\mathrm{g})$ and $\mathrm{W}_{\mathrm{ds}}$ is the weight of dried seaweed $(\mathrm{g})$ used for extraction.

\section{$\underline{\text { Viscosity }}$}

A $2.25 \mathrm{~g}$ dried carrageenan was placed in a tare-weight of $250 \mathrm{ml}$ beaker. A $0.30 \mathrm{~g} \mathrm{KCl}$ and distilled water were added to the carrageenan until a $150 \mathrm{~g}$ tare weight was reached. The beaker was placed in the water bath to dissolve the carrageenan. The solution was heated using microwave oven. After re-weighed, the solution was heated again to more than $75^{\circ} \mathrm{C}$. The viscosity jar was filled with solution to the marked level. The jar was inserted in Brookfield Synchro-lectric nViscometer Model LVF. The viscosity of the solution was read at $75^{\circ} \mathrm{C}$ (Romero 2009; Romero et al. 2000).

\section{$\underline{\text { Gel Strength }}$}

Thirty (30) $\mathrm{ml}$ of carrageenan solution was placed in a 50ml beaker and allowed to cool overnight. The gel strength was measured using Gel texture analyzer and it was computed using equation below (Romero et al. 2000).

$$
\mathrm{GS}=\frac{F}{\mathrm{~A}}
$$

where GS is gel strength $\left(\mathrm{g} \mathrm{cm}^{-2}\right), \mathrm{F}$ is the force $(\mathrm{g})$ and $\mathrm{A}$ is an area which was obtained from the gel tester analyzer with a constant value of $1.26677 \mathrm{~cm}^{2}$.

\section{$\underline{\text { Gelling and Melting Temperatures }}$}

The $10 \mathrm{ml} / \mathrm{tt}$ remaining hot solution was put in a test tube. A thermometer with its bulb situated just below the solution surface was inserted through a stopper. The solution was allowed to cool and glass beads (dia: $2.85 \mathrm{~mm}$; wt: $30 \mathrm{~g}$ ) was dropped at intervals of $0.5^{\circ} \mathrm{C}$. The temperature was recorded at which a bead failed to drop through the agar solution. This 
is the gelling temperature of the solution.The gel set-up used in gelling temperature determination was allowed to cool overnight. The set-up was placed in an electric heated water bath and heated slowly. A lead shot (dia: 4.30mm; wt: 50mg) was placed on the gel surface. The temperature at which the lead shot dropped to the bottom of the test tube was recorded as the melting temperature (Romero 2009; Romero et al. 2000).

\section{Syneresis Index}

Ten (10) g gel solution was placed in a cylindrical tube (5cm length) and allowed to cool overnight and then, it was weighed. The gel was individually placed on filter papers and allowed to stand for 2 hours. The test tube was weighed to get the weight of the gel and the gel was weighed after 2 hours. The difference in the weight represents the amount of water exuded by the gel upon standing. Syneresis index was determined using equation below (Romero et al. 2000).

$$
\mathrm{I}=\frac{\mathrm{Wi}-\mathrm{Wf}}{\mathrm{Wi}} \times 100
$$

where $\mathrm{I}$ is the syneresis index $(\%), \mathrm{W}_{\mathrm{i}}$ is the initial weight of the gel $(\mathrm{g})$ and $\mathrm{W}_{\mathrm{f}}$ is the final weight of the gel after standing for 2 hours.

\section{Statistical Analysis}

The significant difference on the growth rate, "ice-ice" disease occurrence and carrageenan quality of Kappaphycus striatus was subjected to Two-way Analysis of Variance (ANOVA) using SPSS software version 20 (SPSS Inc.). A Post hoc test (LSD) was used to rank the means.

\section{RESULTS}

\section{Growth}

After 45 days of culture, the average final weight, weight gained, daily growth increment (DGI) and specific growth rate (SGR) of K. striatus enriched with organic fertilizers with two levels of concentrations are presented in Table 1. Results revealed that $T_{3}$ was highly significant $(\mathrm{p}<0.05)$ than those of the four treatments. Results also showed that $T_{2}, T_{4}$ and $T_{5}$ were significantly higher $(\mathrm{p}<0.05)$ than $\mathrm{T}_{1}$.

Table 1: Average final weight, weight gained, daily growth increment (DGI) and specific growth rate (SGR) of $K$. striatus enriched with organic fertilizers after 45 days culture periods. Values with different letters are significantly different at $p<0.05$

\begin{tabular}{|c|c|c|c|c|}
\hline Treatments & Final Wt. (g) & Wt. Gained (g) & DGI (g) & SGR (\% day $\left.{ }^{-1}\right)$ \\
\hline $\mathrm{T}_{1}-$ Control & $134.87 \pm 1.27$ & 84.07 & 1.87 & $2.17 \pm 0.020^{\mathrm{a}}$ \\
\hline $\mathrm{T}_{2}-0.1 \mathrm{~g} \mathrm{~L}^{-1}$ AMPEP & $141.60 \pm 0.20$ & 90.70 & 2.02 & $2.27 \pm 0.003^{\mathrm{b}}$ \\
\hline $\mathrm{T}_{3}-8.82 \mathrm{~g} \mathrm{~L}^{-1}$ AMPEP & $148.40 \pm 0.31$ & 97.50 & 2.17 & $2.38 \pm 0.003^{\mathrm{c}}$ \\
\hline $\mathrm{T}_{4}-0.1 \mathrm{~g} \mathrm{~L}^{-1}$ Padina & $139.13 \pm 0.29$ & 88.53 & 1.97 & $2.27 \pm 0.012^{\mathrm{b}}$ \\
\hline $\mathrm{T}_{5}-8.82 \mathrm{~g} \mathrm{~L}^{-1}$ Padina & $140.33 \pm 0.18$ & 89.73 & 1.86 & $2.27 \pm 0.003^{\mathrm{b}}$ \\
\hline
\end{tabular}

The average specific growth rates(SGR) of farmed K.striatustreated with organic fertilizers with two levels of concentrations in three sampling periods are presented in Table 2. Resultsrevealed that $\mathrm{T}_{3}$ was significantly higher $(\mathrm{p}<0.05)$ 
than those of the four treatments throughout the sampling periods.

Table 2: Average specific growth rate $\left(\% \mathrm{day}^{-1}\right)$ of $K$. striatus enriched with organic fertilizers in three sampling periods. Values with different letters are significantly different at $\mathbf{p}<0.05$

\begin{tabular}{|c|c|c|c|}
\hline Treatments & Day 15 & Day 30 & Day 45 \\
\hline $\mathrm{T}_{1}-$ Control & $2.45 \pm 0.133^{\mathrm{a}}$ & $2.51 \pm 0.035^{\mathrm{a}}$ & $2.17 \pm 0.020^{\mathrm{a}}$ \\
\hline $\mathrm{T}_{2}-0.1 \mathrm{~g} \mathrm{~L}^{-1}$ AMPEP & $2.80 \pm 0.067^{\mathrm{ac}}$ & $2.59 \pm 0.011^{\mathrm{a}}$ & $2.27 \pm .0003^{\mathrm{b}}$ \\
\hline $\mathrm{T}_{3}-8.82 \mathrm{~g} \mathrm{~L}^{-1}$ AMPEP & $3.97 \pm 0.103^{\mathrm{b}}$ & $3.00 \pm 0.003^{\mathrm{b}}$ & $2.38 \pm 0.003^{\mathrm{c}}$ \\
\hline $\mathrm{T}_{4}-0.1 \mathrm{~g} \mathrm{~L}^{-1}$ Padina & $2.87 \pm 0.087^{\mathrm{ad}}$ & $2.55 \pm 0.003^{\mathrm{a}}$ & $2.27 \pm 0.012^{\mathrm{b}}$ \\
\hline $\mathrm{T}_{5}-8.82 \mathrm{~g} \mathrm{~L}^{-1}$ Padina & $2.96 \pm 0.272^{\mathrm{cd}}$ & $2.51 \pm 0.085^{\mathrm{a}}$ & $2.27 \pm 0.003^{\mathrm{b}}$ \\
\hline
\end{tabular}

\section{Occurrenceof "Ice-ice" Disease}

The percentage of "ice-ice" disease occurrence of farmed $K$. striatusenriched with AMPEP and Padina liquid extract with two levels of concentrations in three sampling periods is shown in Table 4.3. The "ice-ice" disease occurrence was observed after 30 days of culture. Results revealed that $\mathrm{T}_{3}(18.96 \pm 2.3 \%)$ was significantly lowercompared to $\mathrm{T}_{2}$ (19.98 $\pm 1.7 \%), \mathrm{T}_{1}(20.1 \pm 1.6 \%), \mathrm{T}_{5}(27.84 \pm 0.89 \%)$ and $\mathrm{T}_{4}(28.38 \pm 1.03 \%)$ but $\mathrm{T}_{3}$ was not significantly different with $\mathrm{T}_{2}$ on the $30^{\text {th }}$ day of culture. On the $45^{\text {th }}$ day of culture, results revealed that $\mathrm{T}_{2}$ and $\mathrm{T}_{3}$ were significantly lower with $28.17 \pm 2.4 \%$ and $27.63 \pm 2.8 \%$, respectively $(\mathrm{p}<0.05)$.

Table 3: Percentage (\%) of "ice-ice" disease occurrence in farmed $K$. striatus in three samplings during 45 days of cultivation. Values with different letters are significantly different at $\mathbf{p}<0.05$

\begin{tabular}{|c|c|c|c|}
\hline Treatments & Day 15 & Day 30 & Day 45 \\
\hline T1 - Control & 0 & $24.10 \pm 1.583 \mathrm{ad}$ & $45.27 \pm 3.948 \mathrm{a}$ \\
\hline T2 $-0.1 \mathrm{~g} \mathrm{~L}-1$ AMPEP & 0 & $19.98 \pm 1.689 \mathrm{ac}$ & $28.17 \pm 2.405 \mathrm{~b}$ \\
\hline T3 -8.82 g L-1 AMPEP & 0 & $18.96 \pm 2.287 \mathrm{c}$ & $27.63 \pm 2.755 \mathrm{~b}$ \\
\hline T4 -0.1 g L-1Padina & 0 & $28.38 \pm 1.030 \mathrm{~d}$ & $43.99 \pm 5.097 \mathrm{a}$ \\
\hline T5 -8.82 g L-1Padina & 0 & $27.84 \pm 0.892 \mathrm{~d}$ & $39.22 \pm 1.963 \mathrm{a}$ \\
\hline
\end{tabular}

\section{Carrageenan Quality}

The moisture content, carrageenan yield, viscosity, syneresis, gel strength, gelling temperature and melting temperature $K$. striatus are presented in Table 4.5. Results showed that $\mathrm{T}_{3}$ was significantly higher on carrageenan yield and syneresis index with $26.47 \pm 1.89 \%$ and $13.7 \pm 0.34 \%$, respectively, and significantly lower in gel strength with $249.03 \pm 3.98 \mathrm{~g} \mathrm{~cm}^{-2}$ $(\mathrm{p}<0.05)$, but it was not significantly different $(\mathrm{p}>0.05)$ on the moisture content, viscosity, gelling and melting temperatures with $32.0 \pm 0.55 \%, 15.0 \pm 2.84 \%, 40^{\circ} \mathrm{C}$ and $50.0 \pm 3.46^{\circ} \mathrm{C}$, respectively.. Results also revealed that $\mathrm{T}_{2}$ was significantly higher in gel strength with $333.34 \pm 4.43 \mathrm{~g} \mathrm{~cm}^{-2}$ than $\mathrm{T}_{1}, \mathrm{~T}_{3}$ and $\mathrm{T}_{4}$ but it was not significantly different with $\mathrm{T}_{5}$ $(\mathrm{p}<0.05)$. 
Table 4: Carrageenan quality of dried $K$. striatus after 45 days of culture.

Values with different letters are significantly different at $p<0.05$

\begin{tabular}{|c|c|c|c|c|c|c|c|}
\hline $\begin{array}{c}\text { Treatment } \\
\text { S }\end{array}$ & $\begin{array}{l}\text { Moisture } \\
\text { content of } \\
\text { dried } \\
\text { seaweed } \\
(\%)\end{array}$ & Yield (\%) & $\begin{array}{l}\text { Viscosity } \\
\text { (cPs) }\end{array}$ & $\begin{array}{l}\text { Syneresis } \\
\text { index }(\%)\end{array}$ & $\begin{array}{l}\text { Gel strength } \\
\qquad\left(\mathrm{g} \mathrm{cm}^{-2}\right)\end{array}$ & $\begin{array}{c}\text { Gelling } \\
\text { temperatu } \\
\text { re }\left({ }^{\circ} \mathrm{C}\right)\end{array}$ & $\begin{array}{c}\text { Melting } \\
\text { temperatur } \\
\text { e }\left({ }^{\circ} \mathrm{C}\right)\end{array}$ \\
\hline $\begin{array}{c}\mathrm{T}_{1}- \\
\text { Control }\end{array}$ & $33.75 \pm 0.20^{\mathrm{a}}$ & $\begin{array}{c}21.27 \pm 0.83 \\
\mathrm{~b}\end{array}$ & $\underset{\mathrm{a}}{15.50 \pm 2.26}$ & $\underset{\mathrm{c}}{10.74 \pm 0.39}$ & $302.61 \pm 1 \pm 11.92^{b}$ & $\underset{\mathrm{a}}{39.00 \pm 0.58}$ & $51.33 \pm 0.67^{\mathrm{a}}$ \\
\hline $\begin{array}{c}\mathrm{T}_{2}-0.1 \mathrm{~g} \\
\mathrm{~L}^{-1} \text { AMPEP }\end{array}$ & $31.85 \pm 0.58^{\mathrm{b}}$ & $22.11 \pm 0.16$ & $\begin{array}{c}12.67 \pm 1.67 \\
\text { a }\end{array}$ & $\underset{\mathrm{ab}}{12.25 \pm 0.45}$ & $333.34 \pm 4.432^{\mathrm{a}}$ & $\underset{\mathrm{a}}{40.67 \pm 0.33}$ & $51.67 \pm 4.10^{\mathrm{a}}$ \\
\hline $\begin{array}{c}\mathrm{T}_{3}-8.82 \mathrm{~g} \\
\mathrm{~L}^{-1} \text { AMPEP }\end{array}$ & $32.00 \pm 0.55^{\mathrm{ab}}$ & $\begin{array}{c}26.47 \pm 1.89 \\
\text { a }\end{array}$ & $\begin{array}{c}15.00 \pm 2.84 \\
\mathrm{a}\end{array}$ & $\underset{\mathrm{a}}{13.70 \pm 0.34}$ & $249.03 \pm 3.987^{\mathrm{d}}$ & $\begin{array}{c}40.00 \pm 0.00 \\
\mathrm{a}\end{array}$ & $50.00 \pm 3.46^{\mathrm{a}}$ \\
\hline $\begin{array}{l}\mathrm{T}_{4}-0.1 \mathrm{~g} \\
\mathrm{~L}^{-1} \text { Padina }\end{array}$ & $32.57 \pm 0.66^{\mathrm{ab}}$ & $\underset{\mathrm{b}}{24.09 \pm 0.36}$ & $\underset{\mathrm{a}}{12.00 \pm 1.26}$ & $10.95 \pm .60^{b c}$ & $300.16 \pm 2.637^{\mathrm{c}}$ & $\begin{array}{c}40.00 \pm 0.00 \\
\mathrm{a}\end{array}$ & $48.67 \pm 3.84^{\mathrm{a}}$ \\
\hline $\begin{array}{l}\mathrm{T}_{5}-8.82 \mathrm{~g} \\
\mathrm{~L}^{-1} \text { Padina }\end{array}$ & $32.15 \pm 0.77^{\mathrm{ab}}$ & $21.91 \pm 1.05$ & $\begin{array}{c}13.00 \pm 2.02 \\
\mathrm{a}\end{array}$ & $\underset{\mathrm{c}}{10.42 \pm 0.54}$ & $320.76 \pm \underset{b}{b} \pm 604^{\mathrm{a}}$ & $\underset{\mathrm{a}}{40.00 \pm 0.00}$ & $45.33 \pm 2.96^{\mathrm{a}}$ \\
\hline
\end{tabular}

\section{DISCUSSIONS}

\section{Growth}

In this study, the farmed seaweed Kappahycus striatus enriched with AMPEP $\left(8.82 \mathrm{~g} \mathrm{~L}^{-1}\right)$ obtained highest specific growth rate $\left(2.38 \pm 0.003 \%\right.$ day $\left.^{-1}\right)$ after 45 days of culture. Enriched $K$. striatus grew faster due to an efficient absorption of nutrients during fertilization with AMPEP (Hurtado et al. 2011). Nutrient enrichment could significantly increase growth for K. alvarezii (Luhan et al. 2014). The result of this study was similar to $2.4-3.0 \%$ day $^{-1}$ K. alvarezii (Borlongan et al. 2010),3.1-4.1\% day ${ }^{-1}$ K. alvarezii (Hurtado et al. 2011), 2.00\% day ${ }^{-1}$ in the K. alvarezii dipped with AMPEP(Zuldin and Sapawi 2015), and 1.3-4.1\% day ${ }^{-1}$ for $K$. alvarezii enriched with AMPEP under laboratory conditions (Loureiro et al. 2009). There have been few studies on the use of inorganic fertilizers and seaweed extract as a growth promoter in farmed seaweed Kappaphycus.A recent study conducted by Tahiluddin (2019) on farmed K. striatus enriched with ammonium phosphate (16-20-0) at high concentration $\left(8.82 \mathrm{~g} \mathrm{~L}^{-1}\right)$ attained the SGR of $3.75 \%$ day $^{-1}$ during poor season. Luhan et al. (2014) obtained SGR of $0.53-0.40 \%$ day $^{-1}$ enriched with nitrogen (N) for K. alvarezii cultured in tank.Rui et al. (1990) obtained SGR of $4.6 \%$ day $^{-1}$ fertilized with 10ppm ammonium K. alvarezii.

The Padina liquid extract applied to farmed seaweed K. striatus could also increasegrowth rate $\left(2.28 \%\right.$ day $\left.^{-1}\right)$. All these of available information on seaweed Padina extracts were applied in agricultural crops. Padina liquid extract can provide macronutrients and trace elements necessary for the growth of plants (Chbani et al. 2013). Seaweed Padina liquid fertilizers also contain higher amount of water-soluble potash, other minerals and trace elements which are readily absorbed by plants (Kumareswari and Rani 2015).

\section{Occurrence of "Ice-ice" Disease}

It was observed that "ice-ice" disease occurred after 30 days of culture. The seaweed K. striatus treated with AMPEP obtained the lowest percentage $(18.96 \pm 2.29 \%)$ and $(27.63 \pm 2.76 \%)$ of "ice-ice” disease occurrence during 30 day and 45 days of culture, respectively. The AMPEP is more efficient organic fertilizer in reducing the occurrence of "ice-ice" disease in farmed K. striatus (Zuldin and Shapawi 2015). Despite the optimum physio-chemical parameters of the seaweed 
farm, the "ice-ice" disease occurred during March. The optimum physio-chemical parameters for Kappaphycus should range between 33-35 ppt (Largo 2002), 20 - $32{ }^{\circ} \mathrm{C}$ (Largo et al. 1995a; De San 2012). High stocking density and seaweed overcrowding (Largo et al. 1995a) and high incidence of epiphytes could contribute to the occurrence of "ice-ice" disease (Uyenco et al. 1981; Trono and Ohno 1989; Largo et al. 1995a).

The application of AMPEP to seaweed farming could inhibit occurrence of "ice-ice" disease and pathogenic and epiphyte infestations (Borlongan et al. 2010). Luhan et al. (2014) reported that occurrence of "ice-ice" disease reached as $97 \%$ for control while $K$. alvarezii enriched with sodium nitrate could significantly lower to $8.75 \%$ in cage culture. The "ice-ice" affected seaweeds would disintegrate and resulted to poor quality crops and production (Tisera and Naguit 2009). The "ice-ice" disease outbreak has become a major problem for seaweed farmers who do have other alternative means of livelihood.

\section{Analysis of Carrageenan Quality}

Carrageenan quality and properties can vary among seaweed species depending on the culture technique (Azanza-Corrales 1990; Trono and Lluisma 1992), farm site and its environmental parameters (Hayash et al. 2007), the extraction process (Villanueva et al. 2003) and the nutrient enrichment (Luhan et al. 2014).

The moisture content obtained in this study (Table 4) met the standard moisture content requirement (ranging 30 $39 \%$ ) for top quality dried seaweed. The average 35\% moisture content referred to as the most stable dried seaweed. Moisture content of the seaweed is very critical factor which can affect its carrageenan quality and eventually its market price (Hurtado and Agbayani 2000). Highest carrageenan yield (26.47 $\pm 1.89 \%$ ) was obtained from K. striatusenriched with AMPEP $\left(8.82 \mathrm{~g} \mathrm{~L}^{-1}\right)$ followed by $24.09 \pm 0.36 \%$ from Padina liquid extract $\left(8.82 \mathrm{~g} \mathrm{~L}^{-1}\right)$. The carrageenan yields may vary depending on the extraction method and the strain or variant species of seaweeds (Mohammad-Akhmal et al. 2017). In this study, carrageenan yieldwas quite similar to that reported by Mohammad-Akhmal et al. (2017) which ranged from 20.428.4\% and Hayashi et al. (2007) obtained 15-20\% for Kappaphycus sp.. Munoz et al. (2004) reported higher carrageenan yield (30.3 to $40.7 \%$ ) of brown, green and red strains of $K$. alvarezii.Hurtado-Ponce (1995) reported that yield could be as low as $15.00 \%$ and Mendoza et al. (2002) as high as 64.00\% in Kappaphycus. Luhan et al. (2014) obtained $42.55 \%$ for K. alvarezii enriched with sodium nitrate and $33.05 \%$ for control. Pathik et al (2006) reported that K. alvarezii extract yielded $62.40 \%$ treated with $\mathrm{KOH}$ and $2.8-72.9 \%$ with $\mathrm{NaOH}$. The variation in carrageenan yield could possibly differ due to the extraction method and process (Mohammad-Akhmal et al. 2017).

The organic fertilizers did not affect the viscosity of the alkali-treated carrageenan. The viscosity obtained from this study was similar to that reported by Pathik et al. (2006) which ranged from $12.94-25.25$ cPs in K. alvarezii. Other studies obtained viscosity of $16.17 \pm 17 \mathrm{cPs}$ in $K$. alvarezii (Dewi et al. 2014), $18.00 \mathrm{cPs}$ in K. striatum (Mendoza et al. 2006), and $20.0 \mathrm{cPs}$ in K. striatum (Mendoza et al. 2002). Hurtado-Ponce (1995) obtained viscosity ranged from 23.0 $2.0-34.5 \pm 1.5 \mathrm{cPs}$ in $K$. alvarezii. Krechhoff et al. (2015) obtained viscosity ranged from 30.0-60.0 cPs in $K$. alvarezii. The organic fertilizers could affect gelling temperature of the alkali-treated carrageenan. K. striatus treated with organic fertilizers obtained high gelling temperature. Gelling temperature is the temperature for initial development of gel networks through formation of helices and junction zones upon cooling (Lai and Lii 1997). The gelling temperature obtained in this study was similar with other studies such as $39.3 \pm 0.3{ }^{\circ} \mathrm{C}$ in K. striatum (Mendoza et al. 2006) and 32.7 $\pm 0.3-34.5 \pm 0.9{ }^{\circ} \mathrm{C}$ in K. striatum (Mendoza et al. 2002). Hurtado-Ponce (1995) obtained gelling temperature in $K$. 
alvareziiranged from $8.6 \pm 1.6-17.3 \pm 1.3{ }^{\circ} \mathrm{C}$. The organic fertilizers did not affectmelting temperature of the alkali-treated carrageenan.The melting temperature corresponds of the dissociation of the most cross-linked junction zones of gel upon heating (Lai and Lii 1997). The melting temperature obtained in this study was similar with other studies such as $53.0 \pm 2.6$ ${ }^{\circ} \mathrm{C}$ in K. striatum (Mendoza et al. 2006) and $52.0 \pm 1.8-56.2 \pm 2.5{ }^{\circ} \mathrm{C}$ in K. striatum (Mendoza et al. 2002). Hurtado-Ponce (1995) obtained melting temperature in $K$. alvareziiranged from $46.5 \pm 0.5-67.5 \pm 0.5{ }^{\circ} \mathrm{C}$.

The AMPEP enhanced the syneresis index of the alkali-treated carrageenan (Table 4). The syneresis index (\%) expresses the amount of water exuded from the gel matrix after standing for certain period of time (Rees 1969; Armisen and Galatas 1987). The syneresis index (Fiszman and Duran 1992) as modified by Romero et al. (2000) indicates the extent of interaction between and among polymers. The index represents the water holding capacity of the gel. Less water exuded from the gel means high water holding capacity. The amount of synerized water may vary among species of seaweed and between the extraction methods (Romero 2009). These results were lower than to the syneresis index reported by Mendoza et al. (2002) which ranged (15.4 $\pm 3.3-25.2 \pm 2.7 \%)$ extracted from K. striatum.

The organic fertilizers could affect the gel strength of the alkali-treated carrageenan.K. striatus enriched with 0.01 $\mathrm{g} \mathrm{L}^{-1}$ AMPEP obtained the highest gel strength of $333.34 \pm 4.43 \mathrm{~g} \mathrm{~cm}^{-2}$ followed by $320.76 \pm 4.60 \mathrm{~g} \mathrm{~cm}^{-2}$ from $8.82 \mathrm{ml} \mathrm{L}^{-}$ ${ }^{1}$ Padina liquid extract. The gel strength of agar or carrageenan is an important parameter in distinguishing the gel quality for the use in bacteriological and biomedical applications and food industry (Yaphe and Duckworth 1972). The gel strengths obtained from this study were higher than other studies such as $131.0 \pm 8.0 \mathrm{~g} \mathrm{~cm}^{-2}$ in K. alvarezii (Hurtado-Ponce 1995 ) and 37.0 $\pm 5.6-146.5 \pm 25.6 \mathrm{~g} \mathrm{~cm}^{-2}$ in K. striatum (Mendoza et al. 2002). These results were lower than those reported by previous studies such as $504.3 \pm 11.8 \mathrm{~g} \mathrm{~cm}^{-2}$ in $K$. striatum (Mendoza et al. 2006) and $776.53 \pm 37.15 \mathrm{~g} \mathrm{~cm}^{-2}$ in $K$. alvarezii (Dewi et al. 2014). Luhan et al. (2014) obtained gel strength of $672 \mathrm{~g} \mathrm{~cm}^{-2}$ for $K$. alvarezii enriched with $10 \mathrm{ppm}$ sodium nitrate and $613 \mathrm{~g} \mathrm{~cm}^{-2}$ for control. Mohammad-Akhmal et al. (2017) reported gel strength ranged from $484-712 \mathrm{~g}$ $\mathrm{cm}^{-2}$ for Kappaphycus spp. treated with KOH. Krechhoff et al. (2015) obtained gel strength which ranged from 557-1,391 $\mathrm{g} \mathrm{cm}^{-2}$ in K. alvarezii.

\section{CONCLUSIONS}

The use of Acadian Marine Plant Extract Powder (AMPEP) with high concentration has very efficient effect on growth performance on farmed Kappaphycus striatus. The AMPEP could also be an effective agent in minimizing the occurrence of "ice-ice" disease on farmed $K$. striatus. High concentration of AMPEP could produce higher carrageenan yield of $K$. striatus. Padina sp. could also be good alternative as organic fertilizer used in seaweed farming because this could increase growth on K. striatus and produce high carrageenan yield.Thus, organic fertilizers (AMPEP and Padina liquid extract) could enhance faster growth and reduce occurrence of "ice-ice" disease on farmed K. striatus.

\section{RECOMMENDATIONS}

It is recommended that other studies on the use of organic fertilizers in seaweed farming should be conducted at different level of concentrations and with different farming methods and techniques. Other studies should also investigate on the carrageenan quality and properties in terms of culture periods using the same fertilizers in seaweed cultivation. 


\section{ACKNOWLEDGEMENT}

I wish to express my sincere thanks and gratitude to the Chancellor of MSU - TCTO, Mary Joyce Z. Guinto - Sali, Ph.D.and members of the APC, for approving the renewal and extension of my study grant under Academic Personnel Development Program (APDP);Prof. Albaris B. Tahiluddin, my adviser, for his valuable guidance from the initial idea to the final draft of my thesis.

\section{REFERENCES}

1. Arasamuthu, A. and J.K.P. Edward (2016). Occurrence of "ice-ice" Disease in Seaweed Kappaphycus alvarezii at Gulf of Mannar and Palk Bay, Southeastern India. Indian Journal of Geo Marine Sciences Vol. 47 (06):1208-1216.

2. Armisen, R. and F. Galatas (1987). Production, properties and uses of agar. In: McHugh, D.J. (ed). Production and utilization of products from commercial seaweeds. FAO Fisheries Technical Papers 288. Pp.1 - 57. In:

3. Amin, Bengag, Allem Rachida, and Bekara Amina. "Anti-Inflammatory Activity of Citru Sessences Harvested Locally in Chlef Region (Algeria): In Vivo Study." International Journal of Applied and Natural Sciences (IJANS) 4.5 (2015): 21-30.

4. Azanza, R.V. and E. Ask (2017). Reproductive Biology and Eco-physiology of Farmed Kappaphycus and Eucheuma. Tropical Seaweed Farming Trends, Problems and Opportunities.

5. Azanza-Corrales, R. (1990). The farmed Eucheuma species (Gigartinales, Rhodophyta) in Danajon Reef, Philippines: carrageenan properties. Hydrobiologia, v. 204-205, p. 521-525, 1990. http://dx.doi.org/10.1007/BF00040280. In: Webber, V., S.M. Calvalho, P.J. Ogliari, L. Hayashi and P.L.M. Barreto. 2012. Optimization of the extraction of carrageenan from Kappaphycus alvarezii using response surface methodology. Ciência e Tecnologia de Alimentos. Ciênc. Tecnol. Aliment., Campinas, 32(4): 812-818.

6. Bixler, H.H.J. \&, H. Porse (2011). A decade of change in the seaweed hydrocolloids industry. Journal of Applied Phycology, 23: $321-335$.

7. Bjerregaard, R., Valderrama, D., Radulovich, R., Diana, J., Capron, M., Mckinnie, C.A., Cedric, M., Hopkins, K., Yarish, C., Goudey, C. \& Forster, J. (2016). Seaweed aquaculture for food security, income generation and environmental health in Tropical Developing Countries. World Bank Group, Washington, DC.

8. Borlongan I.A.G., K.R. Tibubos, D.A.T. Yunque, A.Q. Hurtado, and A.T. Critchley. (2010). Impact of AMPEP on the growth and occurrence of epiphytic Neosiphonia infestation on two varieties of commercially cultivated Kappaphycus alvarezii grown at different depths in the Philippines. Journal of Applied Phycology 23:615 - 621.

9. Burtin, P. (2003). Nutritional value of seaweeds. Electronic Journal of Environmental, Agricultural and Food Chemistry, 2(4), $498-503$

10. Chbani, A., H. Mawlawi and L. Zaouk (2013). Evaluation of brown seaweed (Padina pavonica) as biostimulant of plant growth and development. African Journal of Agricultural Research. Academic Journals.

11. Dawes, C.J., A.O. Lluisima, and G.C. Trono (1994). Laboratory and field growth studies of commercial strain of Eucheuma denticulatum and Kappaphycus alvarezii in the Philippines. Journal of Applied Phycology 6:21 - 24.

12. De San, M. (2012). The Farming of Seaweeds.SmartFish Programme Report SF/2012/28.Agrotec. Indian Ocean Commission.

13. Dewi, E.N., R. Ibrahim and S. Suharto (2014). Morphological structure characteristics and quality of semi-refined carrageenan processed by different drying methods. International Conference on Tropical and Coastal Region EcoDevelopment. Science Direct. Elsevier. 
14. Dhargalkar and Pereira (2005). Seaweed: Promising Plant of the millennium, Sci. Cult. 71:60-66. In: Chbani, A., S. Majed, H. Mawlawi.2015.Mineral Content of Mediterranean Seaweeds, Padina pavonica (Pheophytae), Ulva lactuca and Ulva linza (Chlorophytae) for Biofertilizing Use.International Journal of Horticultural Science and Technology Vol. 2, No. 2;, pp 133140

15. Doty, M.S. (1986). The Production and Uses of Eucheuma. In: Case Studies of Seven Commercial Seaweed Resources. Doty, M.S., J.F. Caddy and B. Stantelices (eds). FAO Fish Tech. Pap. 282: 123-164. In: Hurtado and Agbayani 2000. The Farming of the Seaweed Kappaphycus. Aquaculture Extension Manual no. 32. SEAFDEC. Tigbauan, Iloilo, Philippines.

16. FAO (2017). The state of world fisheries and aquaculture, Available from: http://www.fao.org/fishery/en. Accessed Jan 23, 2017.

17. FAO (1989). Culture of Kelp (Laminaria japonica). Training manual 89/5 (RAS/86/024) (http://www.fao.org/docrep/field/003/AB724E/AB724E00.htm).

18. FAO (2007). FAO JECFA Monographs 4. Specifications: Carrageenan., available at: http://www.fao.org/ag/agn/jecfaadditives/details. $h$ tml $?$ id $=830$

19. FAO (2016). The State of World Fisheries and Aquaculture 2016 (SOFIA).

20. FAZILI, MOHAMMAD AFAAN, ABDUL HAMID WANI, and MOHD YAQUB BHAT. "EFFECT OF DIFFERENT DOSES OF GAMMA-IRRADIATED SODIUM ALGINATE AND NITROGEN FERTILIZER ON GROWTH, PHYSIOLOGY AND YIELD ATTRIBUTES OF MENTHA PIPERITA L. IN NORTHERN HIMALAYAS. "International Journal of Agricultural Science and Research (IJASR) 7. 4, Aug 2017, 165-176

21. Fiszman, S.M. and L. Duran (1992). Effects of fruit pulp and sucrose on the compression reponse of different polysaccharides gel systems. Carbohydr. Polym. 17:11-17. In:

22. Ganzon-Fortes, E.T., R. Corrales and T.. Aliaza. 1993. Comparison of phoyosynthetic responses of healthy and diseased Kappaphycus alvrezii (Doty) Doty using P vs/curve. Botanica Marina 36:501-506.

23. Guiry, M.D. 2000. The Seaweed Site. Information on marine algae. Article.

24. Hayashi, L., E.J. Paula and F. Chow (2007). Growth rate and carrageenan analyses in four strains of Kappaphycus alvarezii (Rhodophyta, Gigartinales) farmed in the subtropical waters of São Paulo State, Brazil. Journal of Applied Phycology, v. 19, p. 393-399, 2007. http:// dx.doi.org/10.1007/s10811-006-9135-6. In: Webber, V., S.M. Calvalho, P.J. Ogliari, L. Hayashi and P.L.M. Barreto. 2012. Optimization of the extraction of carrageenan from Kappaphycus alvarezii using response surface methodology. Ciência e Tecnologia de Alimentos. Ciênc. Tecnol. Aliment., Campinas, 32(4): 812-818.

25. Heertje, I. (1993). Structure and function of food products: A review. Food Structure, 12, 343-364.

26. Hommersand, M.H. and S. Fredericq (1990). Sexual Reproduction and Cystocarp Development. In Biology of the Red Algae. Cole, K.M. \& R.G. Sheath (Eds. Cambridge University Press.

27. Hood, L. F., \& Allen, J. E. (1977). Ultrastructure of carrageenan-milk sols and gels. Journal of Food Science, 42, $1062-1065$.

28. Hurtado, A.Q. and A.T. Critchley (2013). Impact of acadian marine plant extract powder (AMPEP) in Kappaphycus production. Malaysian Journal of Science 32 (SCS Sp Issue) :239-252 (2013)

29. Hurtado, A. (2003). Farming the seaweed Kappaphycus. SEAFDEC Asian Aquaculture, 25(3), 23.

30. Hurtado, A.Q. (2013). Social and economic dimensions of carrageenan seaweed farming in the Philippines. In D. Valderrama, J. Cai, N. Hishamunda, \& N. Reidler (Eds.), Social and Economic Dimensions of Carrageenan Seaweed Farming (pp. 91113). Fisheries and Aquaculture Technical Paper No. 580. FAO, Rome, Italy. 
31. Hurtado, A.Q. and R.F. Agbayani, (2000). The Farming of the Seaweed Kappaphycus. Aquaculture Extension Manual no. 32. SEAFDEC. Tigbauan, Iloilo, Philippines.

32. Hurtado, A.Q., I.T. Neish, and A.T. Critchley (2014). Development in production technology of Kappaphycus in the Philippines; more than four decades of farming. Journal of Applied Phycology 27:1945 - 1961.

33. Hurtado-Ponce, A.Q. (1995). Carrageenan Properties and Proximate Composition of Three Morphotypes of Kappaphycus alvarezii Doty (Gigartinales, Rhodophyta) Grown at Two Depths. Bot Mar 38:215-220. In: Luhan, M.R.J., S.S. Avanceña and J.P. Mateo. 2014. Effect of short-term immersion of Kappaphycus alvarezii (Doty) in high nitrogen on the growth, nitrogen assimilation, carrageenan quality and occurrence of "ice-ice" disease. Journal of Applied Phycology 27(2):917 - 922.

34. Kennedy, J. (2017). Red Algae (Rhodophyta). ThoughtCo. and Dotdash. Article

35. Krechhoff, R.L., Sukoso, B. Yanuwiadi, R. Mangindaan and C.R. Keppel. (2015). Rendenmen, gel strength and viscosity of red algae Kappaphycus alvarezii (Doty) in Minahasa Peninsula. Journal of Biodiversity and Environmental Sciences.

36. Kumar, G. and D. Sahoo (2011). Effect of seaweed liquid extract on growth and yield of Triticum aestivum var. Pusa Gold. J. Appl. Phycol. 23(2):251-255. In: Chbani, A., H. Mawlawi and L. Zaouk. 2013. Evaluation of brown seaweed (Padina pavonica) as biostimulant of plant growth and development. African Journal of Agricultural Research. Academic Journals.

37. Kumareswari, T. and S.M.V. Rani (2015). Utilization of seaweeds Padina to enhance growth and nutritive status of Amaranthus caudatus. International Journal of Research Studies in Bioscience vol. 3, pp. 9-15.

38. Largo, D.B. (2002). Recent development in seaweed disease. In: Hurtado, A.Q., N.G. Guanzon Jr. T.R. de Castro-Mallare and M.R.G. Luhan, (Eds.). Proceeding of the National Seaweed Planning Workshop 35-42.

39. Largo, D.B., K. Fukami, T. Nishijima and M. Ohno. (1995a). Laboratory-induced development of the "ice-ice" disease of the farmed red algae Kappaphycus alvarezii and Eucheuma denticulatum (Solieriaceae, Gigartinales, Rhodophyta). Journal of Applied Phycology 7:539 - 543.

40. Largo, D.B., K. Fukami, T. Nishijima and M. Ohno. (1995b). Occasional pathogenic bacteria promoting "ice-ice" disease in the carrageenan producing red algae Kappaphycus alvarezii and Eucheuma denticulatum (Solieriaceae, Gigartinales, Rhodophyta). Journal of Applied Phycology 7:545 - 554.

41. Largo, D.B., K. Fukami, T. Nishijima and M. Ohno. (1997). Direct enumeration of total bacteria from macroalgae by epifloerescence microscopy as applied to the fleshy red algae Kappaphycus alvarezii (Doty) and Gracilaria spp. (Rhodophyta). Journal of Applied Phycology 33:554 - 557.

42. Loureiro, R.R., R.P. Reis and A.T. Critchley (2010). In vitro cultivation of three Kappaphycus alvarezii (Rhodophyta, Arechougiaceae) variants (green, red and brown) exposed to a commercial extract of the brown alga Ascophyllum nodosum (Fucaceae, Ochrophyta). Journal of Applied Phycology 22:101 - 104.

43. Luhan, M.R.J., S.S. Avanceña and J.P. Mateo (2014). Effect of short-term immersion of Kappaphycus alvarezii (Doty) in high nitrogen on the growth, nitrogen assimilation, carrageenan quality and occurrence of "ice-ice" disease. Journal of Applied Phycology 27(2):917 - 922.

44. Luhan, M.R.J. and H. Sollesta. 2010. Growing the reproductive cells (carpospores) of the seaweeds, Kappapphycus striatum, in the laboratory until outplanting in the field and maturation to tetrasporophyte. Journal of Applied Phycology pp.579-585.

45. Matins, A.P., O.N. Junior, P. Colepicolo and N.S. Yokoya. 2011. Effects of nitrate and phosphate availabilities on growth, photosynthesis and pigment and protein contents in colour strains of Hypnea musciformis (Wulfen in Jacu.) J.V. Lamour (Gigartinales, Rhodophyta). Revista Brasileira de Farmacognosia Brazilian Journal of Pharmacognosy 21(2):340-348. 
46. McHugh, D. J. (2003). Carrageenan. In A guide to the seaweed industry: FAO fisheries technical paper 441. Rome: Food and Agriculture Organization of the United Nations.

47. Mendoza, W.G., E.T. Guanzon-Fortes, R.D. Villanueva, J.B. Romero and N.E. Montaño. 2006. Tissue age as factor affecting carrageenan quality and quantity in farmed Kappaphycus striatum (Schmitz) Doty ex Silva. Botanica Marina 49 (2006):57-64.

48. Mendoza, W.G., N.E. Montaño, E.T. Guanzon-Fortes and R.D. Villanueva. 2002. Chemical and Gelling Profile of "ice-ice" Infected Carrageenan from Kappaphycus striatus (Schmitz) Doty "sakol” Strain (Solieriaceae, Gigartinales, Rhodophyta). Journal of Applied Phycology 14:409-418. In: Luhan, M.R.J., S.S. Avanceña and J.P. Mateo. 2014. Effect of short-term immersion of Kappaphycus alvarezii (Doty) in high nitrogen on the growth, nitrogen assimilation, carrageenan quality and occurrence of "ice-ice" disease. Journal of Applied Phycology 27(2):917 - 922.

49. Menendez, M., J. Herrera and F.A. Comin. 2002. Effect of nitrogen and phosphorous supply on growth, chlorophyll content and tissue composition of the macroalga Chaetomorpha linum (O.F. Mull.) Kutz in a Mediterranean coastal lagoon. Scientia Marina 66(4):355-364.

50. Mohammad Akhmal, I., I. Ahmad and R. Othman. 2017. Analysis of Carrageenan Yield and Gel Strength ofKappaphycusspp. in Semporna, Sabah.J. Trop. Plant Physiol. 9 (2017):14-23. ISSN No 1985-0484 (02017 Malaysian Society of Plant Physiology

51. Msuya, F.E. 2013 Social and economic dimensions of carrageenan seaweed farming in the United Republic of Tanzania. In D. Valderrama, J. Cai, N. Hishamunda, \& N. Reidler (Eds.), Social and Economic Dimensions of Carrageenan Seaweed Farming (pp. 115-146). Fisheries and Aquaculture Technical Paper No. 580. FAO, Rome, Italy.

52. Muñoz, J., Y. Freile-Pelegrin, D. Robledo. 2004. Mariculture of Kappaphycus alvarezii (Rhodophyta, Solieriaceae) color strains in tropical waters of Yucatan, Mexico. Aquaculture 239, 161-177.

53. Nabti, E. , B. Jha, A. Hartmann. 2016. Impact of seaweeds on agricultural crop production as biofertilizer. International journal of Environmental Science and Technology. DOI: 10.1007/s13762-016-1202-

54. NARAGHI, LALEH, and MARYAM NEGAHBAN."THE APPLICATION OF NANOTECHNOLOGY IN DEVELOPING TALAROMYCES FLAVUS FORMULATIONS. "International Journal of Bio-Technology and Research (IJBTR)8. 3, Jun 2018, $1-10$

55. Neish, A.C., P.F. Shacklock, C.H. Foz and F.J. Simpson. 1977. The cultivation of Chondrus cripus. Factors affecting growth under greenhouse conditions. Canadian Journal of Botany 55:2263 -2271.

56. Pang, T., J. Liu, H. Li, and J. Li. 2015. Observation of pests and diseases affecting a eucheumatoid farm in China. Journal of Applied Phycology 27:1975 - 1984.

57. Pathik, C. M., P.C., R. Jayasankar and C. Seema. 2006. Yield and quality of carrageenan from Kappaphycusalvareziisubjected to different physical and chemical treatments. Seaweed Res. Utiln., 28 (1) : 113 - 117.

58. Pereira, R. \& Yarish, C. (2008). Mass production of marine macroalgae. In Ecological Engineering, Vol. 3 of Encyclopedia of Ecology (Jørgensen, S.E. \& Fath, B.D., editors), 2236-2247. Elsevier, Oxford.

59. Pramanick, B., K. Brahmachari, A. Kesarwani, B.S. Mahapatra, D. Ghoshand A. Kumar. 2017.Harnessing Marine Algae Potential in Sustainable Crop Production. Agricultural Research and Technology. Open Access Journal. JUNIPER

60. Reef, R., J.M. Pandolfi and C.E. Lovelock. 2012. The effect of nutrient enrichment on the growth, nucleic acid concentrations and elemental stoichiometry of coral reef macroalgae. Ecology and Evolution 2(8): 1985-1995.

61. Rees, D.A. 1969. Structure, conformation and mechanism in the formation of polysaccharide gels and networks. Adv. 
Carbohydr. Chem. Biochem.24:267-332. In: Romero, J.B. 2009. Yield and rheological properties of agar polysaccharides from some Gracilaria species. MSU-Tawi-Tawi Research Journal. Vol.1:1-14 (2009).

62. Rodrigues, K.F. 2016.Genetic Identification and Mass Propagation of Economically Important Seaweeds. http://dx.doi.org/10.5772/62802/. INTECH

63. Romero, J.B. 2009. Yield and rheological properties of agar polysaccharides from some Gracilaria species. MSU-Tawi-Tawi Research Journal. Vol.1:1-14 (2009).

64. Romero, J.B., M.N.E. Montaño, F.A. Merca, R.G.O. Rumbaoa, and R.D. Villanueva. 2000. Effects of sucrose on some physical properties different Philippine agars. Phil. Jour. Sci. 129 (1): 7 - 13. In: Romero, J.B. 2009. Yield and rheological properties of agar polysaccharides from some Gracilariaspecies. MSU-Tawi-Tawi Research Journal. Vol.1:1-14 (2009).

65. Rui, L., L. Jiajun and C.Y. Wu. 1990. Effect of ammonium on growth and carrageensn content in Kappaphycus alvarezii (Gigartinales, Rhodophyta). S.C. Lindstrom and P.W. Gabrielson (Eds). Thirteenth International Seaweed Symposium Hydrobiologia 204/205:499-503.

66. Snoeren, T. H. M. 1976. Kappa-carrageenan. A study of its physico-chemical properties, sol-gel transition and interactions with milk. (PhD Thesis), Wageningen, The Netherlands.

67. Sofy, M., A.M. Sharaf and M.S. Osman. 2017. Physiological changes, antioxidant activity, lipid peroxidation and yield characters of salt stressed barely plant in response to treatment with Sargassum extract. Impact of seaweeds on agricultural crop production as biofertilizer.International journal of Environmental Science and Technology. DOI: 10.1007/s13762-016$1202-1$

68. Swaisgood, H. E. 1982. Chemistry of milk protein. In P. F. Fox (Ed.), Developments in dairy chemistry (Vol. 1) (pp. 1-59). London, New York: Applied Science Publishers.

69. Tahiluddin, A.B. 2019. Influence of fertilization on the occurrence of vibrio, "ice-ice" disease and growth of seaweed Kappaphycus striatus (F. Schmitz) Doty ex P.C. Silva. Unpublished master's thesis. Institute of Marine Fisheries and Oceanology, University of the Philippines Visayas.

70. Tisera, W.I. and M.R.A. Naguit. 2009. "ice-ice" Disease Occurrence in Seaweed Farms in Bais Bay, Negros Oriental and Zamboanga del Norte. The Threshold 4:1 - 6 .

71. Topinka, 1976. Effects of nitrate and ammonium on growth and nitrogen physiology in Fucus spiralis. Limnology and Oceanography21(5):659-664.

72. Troell, M.,P. Ronnback, C. Halling, N. Kautsky and N. Buchmann. 1999. Ecological engineering in aquaculture: use of seaweed for removing nutrients from intensive mariculture. Journal of Applied Phycology 11:89 - 97.

73. Trono G.C. 1986. Seaweed culture in the Asia-Pacific region. RAPA Publication, 1987/8. Regional Office for Asia and the Pacific, UNFAO.

74. Trono, G.C. and M. Ohno. 1989. Seasonality in biomass production of the Eucheuma strains in Northern Bohol, Philippines. In Umezaki, I. (ed.), Scientific Survey of Marine Algae and their Resources in the Philippine Islands. Technical Report, Monbusho International Scientific Research Program 71-80.

75. Trono, G.C., A.O. Lluisma. 1992. Differences in biomass production and carrageenan yields among four strains of farmed carrageenophytes in Northern Bohol, Philippines. Hydrobiologia, v. 247, p. 223-227, 1992. http://dx.doi.org/10.1007/BF00008222. In: Webber, V., S.M. Calvalho, P.J. Ogliari, L. Hayashi and P.L.M. Barreto. 2012. Optimization of the extraction of carrageenan from Kappaphycus alvarezii using response surface methodology. Ciência e 
Tecnologia de Alimentos. Ciênc. Tecnol. Aliment., Campinas, 32(4): 812-818.

76. Uchida, R. 2000. Essential Nutrients for Plant Growth: Nutrient Functions and Deficiency Symptoms R. Uchida. From: Plant Nutrient Management in Hawaii's Soils, Approaches for Tropical and Subtropical Agriculture J.A. Silva and R. Uchida, eds. College of Tropical Agriculture and Human Resources, University of Hawaii at Manoa.

77. Uyenco, F.R., I.S Saniel and G.S. Jacinto. 1981. The "ice-ice" problem in seaweed farming. In Levring, T. (ed.), Proceeding of the Tenth International Seaweed Symposium 625-630.

78. Valderrama, D., J. Cai, N. Hishamunda, N. Ridler, I.C. Neish, A.Q. Hurtado, F.E. Msuya, M. Krishnan, R. Narayanakumar, M. Kronen, D. Robledo, E. Gasca-Leyva and J. Fraga. 2015. The Economic of Kappaphycus Seaweed Cultivation in Developing Countries: A Comparative Analysis of Farming Systems. Aquaculture Economics \& Management, 19:251-277, 2015. Copyright \# Taylor \& Francis Group, LLC.

79. Valderrama, D., J. Cai, N. Hishamunda \& N. Ridler (Eds.). 2013. Social and Economic Dimensions of Carrageenan Seaweed Farming. Fisheries and Aquaculture Technical Paper No. 580. FAO, Rome, Italy.

80. Van de Velde, F., Lourenco, N. D., Pinheiro, H. M., \& Bakkerd, M. 2002. Carrageenan: A food-grade and biocompatible support for immobilisation techniques. Advanced Synthesis and Catalysis, 344, 815-835.

81. Villanueva, R.D., W.G. Mendozaa, M.R.C. Rodriguezaa, J.B. Romerob, M.N.E. Montañño. 2003. Structure and functional performance of gigartinacean kappa-iota hybrid carrageenan and solieriacean kappa-iota carrageenan blends. Food Hydrocolloids 18 (2004) 283-292. Elsevier Ltd. All rights reserved. doi:10.1016/S0268-005X(03)00084-5

82. Villares, R., X. Puente and A. Carballeira. 1999. Nitrogen and phosphorous in Ulva sp. in the Galician Rias Bajas (Northwest Spain): Seasonal fluctuations and influence on growth. Boletin Instituto Sepañol de Oceanografia 15(1-4):337-341.

83. Vitosh, M.I. 1996. Types, uses and characteristics of N-P-K fertilizers. Michigan State University Extension: Extension Bulletin E-896.

84. Webber, V., S.M. Calvalho, P.J. Ogliari, L. Hayashi and P.L.M. Barreto. 2012. Optimization of the extraction of carrageenan from Kappaphycus alvarezii using response surface methodology. Ciência e Tecnologia de Alimentos. Ciênc. Tecnol. Aliment., Campinas, 32(4): 812-818.

85. White, W. L. and P. Wilson 2015. Seaweed Sustainability. https://www.sciencedirect.com/sciencelarticle/pii/b9780124186972000039

86. Yaphe, W. and M. Duckworth. 1972. The relationship between structures and biological properties of agars. Proc. Int. Seaweed Symp. 7:15-22. In: Romero, J.B. 2009. Yield and rheological properties of agar polysaccharides from some Gracilaria species. MSU-Tawi-Tawi Research Journal. Vol.1:1-14 (2009).

87. Zuldin, W.H. and R. Shapawi. 2015. Performance of red seaweed (Kappaphycu sp.) cultured using tank culture system. Journal of Fisheries and Aquatic Science. 10: 1-12.

\section{AUTHOR'S PROFILE}

He was born on May 15, 1973 in Barangay Umus Mataha, Mapun, Tawi-Tawi, Philippines. He graduated his Bachelor of Science in Fisheries at the Mindanao State University - Tawi-Tawi College of Technology and Oceanography (MSU TCTO) and Master of Science in Aquaculture in the same university. Presently, he is employed as faculty in the College of Fisheries, MSU - TCTO. 